Original Paper http://ajol.info/index.php/ijbcs http://indexmedicus.afro.who.int

\title{
Ant-hemipteran associations in a market-gardening based agro-system in a Yaoundé suburb, Centre Region (Cameroon)
}

\author{
Désirée Chantal ALÉNÉ*, Yveline MATCHINDA MOUKEM, Zéphirin TADU and \\ Champlain DJIÉTO-LORDON
}

\author{
University of Yaounde I, Faculty of Science, Laboratory of Zoology, Department of Animal Biology and \\ Physiology, P. O. Box 812 Yaounde, Cameroon. \\ *Corresponding author; E-mail: chantalalene@yahoo.fr ; Tel: (+237) 697994932.
}

\begin{abstract}
Tritrophic plant-hemipteran-ant relationships are poorly documented in tropical African market-garden agro-systems despite its agronomic importance. The present study aimed at characterizing ant-hemipteran associations on five market crop species at Nkolondom (north-western suburb of Yaoundé): Abelmoschus esculentus, Capsicum annum, Solanum lycopersicum, Solanum melongena and Solanum scabrum. From July to October 2013, twice per week, feeding activities of ants were examined and the occurrence of each ant/hemipteran association recorded per plant species. As result, ants preferentially harvested honeydew excreted by hemipterans. However, Myrmicaria opaciventris and Camponotus flavomarginatus also collected plant sap from wounded organs. Among hemipterans, Aphis fabae, Aphis gossypii, Aulacorthum solani, Macrosiphum euphobiae, scale insects and mealybugs were the most recurrent. The most frequent associations were $M$. opaciventris-A. fabae and C. flavomarginatus-A. fabae on S. scabrum, C. flavomarginatus-M. euphorbiae on S. lycopersicum, C. flavomarginatus-A. solani on C. annuum, M. opaciventris-A. gossypii and Technomyrmex sp.-A. gossypii on $S$. lycopersicum. Some moderately frequent associations viz. $C$. flavomarginatus-M. euphorbiae and M. opaciventris-M. euphorbiae were recorded on S. melongena. For these associations, highly significant and positive correlations was raised between ants' and aphids' populations, suggesting potential mutualistic interactions between the two taxa.
\end{abstract}

(C) 2019 International Formulae Group. All rights reserved

Keywords: Aphids, bugs, feeding behavior, Formicidae, interactions, market crops.

\section{Associations fourmi-hémiptère dans un agrosystème à base de cultures maraîchères dans une banlieue de Yaoundé, Région du Centre (Cameroun)}

\section{RESUME}

Les relations tritrophiques plante-hémiptère-fourmi sont peu étudiées dans les agrosystèmes maraîchers d'Afrique tropicale, malgré leur importance agronomique. La présente étude visait à caractériser les associations fourmi-hémiptères sur cinq espèces de cultures maraîchères à Nkolondom (banlieue nord-ouest de Yaoundé): Abelmoschus esculentus, Capsicum annum, Solanum lycopersicum, Solanum melongena et Solanum scabrum. De juillet à octobre 2013, deux fois par semaine, les activités d'alimentation des fourmis ont été examinées et la présence de chaque association fourmi/hémiptère enregistrée sur chaque espèce végétale. Comme résultat, les fourmis récoltaient principalement le miellat excrété par les hémiptères. Cependant, 
Myrmicaria opaciventris et Camponotus flavomarginatus prélevaient également la sève issue des organes végétaux blessés. Parmi les hémiptères, Aphis fabae, Aphis gossypii, Aulacorthum solani, Macrosiphum euphobiae et les cochenilles étaient les plus récurrents. Les associations les plus fréquentes étaient $M$. opaciventris-A. fabae et C.flavomarginatus-A. fabae sur S. scabrum, C. flavomarginatus-M. euphorbiae sur $S$. lycopersicum, C. flavomarginatus-A. solani sur C. annuum, M. opaciventris-A. gossypii et Technomyrmex sp.A. gossypii sur S. lycopersicum. Quelques associations modérément fréquentes telles que C. flavomarginatus$M$. euphorbiae et $M$. opaciventris-M. euphorbiae ont été enregistrées sur S. melongena. Des corrélations hautement significatives et positives ont été établies entre les populations de fourmis et de pucerons, suggérant des interactions mutualistes potentielles entre les deux taxons.

(C) 2019 International Formulae Group. All rights reserved

Mots clés : Comportement de nutrition, cultures maraîchères, Formicidae, interactions, pucerons, punaises.

\section{INTRODUCTION}

Since the early 1990's in Cameroon, market gardening has become one of the main contributors to food self-sufficiency (Temple, 2001). Its intensification in urban and suburban areas has led to an increase and diversification of pest insects. Among others, hemipterans, especially aphids and true bugs, have been pointed out as one of the main constraints of cultivated plants worldwide (Djiéto-Lordon et al., 2007; Tendeng et al., 2017), although their damage are not always obvious. In addition to sap spoliation, damage due to hemipterans, namely aphids, include localized chlorosis near the feeding site caused by chloroplast disruption, growth distortions on leaves, leaf curling, and sometimes but seldom, galls or tumours (Guerrieri and Digilio, 2008). Sometimes, once infested leaves curl upward, they turn brown, and eventually die and fall down. As for whiteflies, they can directly damage plants by depleting sap, inducing premature defoliation, stunted growth, and potentially death of the plant during population outbreaks (Nasruddin and Stocks, 2014). Damage are vicious when true bugs feed on seedlings and newly transplanted market crops. The feeding punctures are characterised by marks appearing as white patches starting on the edges of leaves as it expands (Palumbo and Natwick, 2010). True bugs such as mirids are well known for abortions they induce on cherelles in cocoa plantations (Mahob et al., 2014, 2018). Other hemipterans, such as aphids, by inserting their mouthparts into plant tissues during sap depletion, inject toxic saliva or pathogens in the plant tissue (Guerrieri and Digilio, 2008). They might be very harmful since they are highly prolific and usually determine outbreaks on growing plants (Guerrieri and Digilio, 2008). Furthermore, by the saliva bearing pathogen injections, hemipterans could act as vectors of some pathogenic microorganisms (Blackman and Eastop, 2000, Jones, 2003; Ng and Perry, 2004; Hampton et al., 2005; Brault et al., 2010). Such threats usually affect plant growth, productivity and, may have a real impact on leaves and fruit yield.

Some hemipterans, especially those living in more or less large colonies, are often associated with one or several ant species (Steiner et al., 2004). Anyway, poor flying hemipterans such as aphids and coccids depend on their tending ants for dispersal. Ants might then play an important role in their dissemination and their spray in and within gardens (Delabie, 2001). They can also amplify or reduce populations and protect them from natural enemies (Stadler and Dixon, 2005; Oliver et al., 2007). In turn hemipterans provide considerable amounts of honeydew, a highly energetic food reward for various insect taxa, especially ants. Moreover, in the absence of ants, the honeydew could negatively affect the growth of hemipteran colonies as well as the fitness of the hostplants due to accumulation of honeydew that favour the development of sooty mold (Lehouck et al., 2004).

Hemipterans and ants have been inventoried on some market-crop species (Aléné et al., unpublished data). These data 
are used in the present study to characterize ant-hemipteran associations. To achieve this, the main food resources exploited by ants on these plants was identified; the diversity and the occurrence of ant-hemipteran associations on each plant species was assessed and the strength of the interaction between ants and hemipterans was characterized.

\section{MATERIALS AND METHODS}

\section{Study site and period}

The present study was carried out at the campus of the University of Yaoundé 1 (03 51' 35,3" N; 11 $30^{\circ}$ ' 0,06”'E; $770 \mathrm{~m}$ asl) and at Nkolondom $\left(03^{\circ} 57^{\prime} 07^{\prime \prime} \mathrm{N}, 11^{\circ} 29^{\prime}\right.$ 27 'E; $645 \mathrm{~m}$ asl) a north-western suburb of Yaoundé.

Field works were conducted from June $21^{\text {st }}$ to October $12^{\text {th }} 2013$. However, the data collecting, was effectively done from July $25^{\text {th }}$ to October $12^{\text {th }} 2013$, including the short dry season and the great rainy season.

\section{Vegetal material}

The biological material involved five market-crop species; four from the family Solanaceae, Capsicum annuиm L. (hot pepper), Solanum lycopersicum L. (tomato), Solanum scabrum Mill. (African nightshade), Solanum melongena L. (sweet eggplant) and one from the family Malvaceae, Abelmoschus esculentus (L.) Moench (okra). These plant species were chosen on the base of their high prevalence in the basin and their permanent production in different local market-oriented cropping zones of Cameroon.

For the experimental plants, seeds of $S$. lycopersicum, S. scabrum, S. melongena and C. аппиит were produced and conditioned by Technisem. Varieties used were "roma savanna" for the tomato, Estrella F1 for pepper, "F1 kalenda" for the sweet eggplant and "royale" for the African nightshade. For okra (var paysan), seed locally produced were bought from Mokolo market in Yaoundé.

\section{Data collecting}

Data were collected twice per week. For each sampling, 30 plants per species were chosen and examined. The inventory was conducted on the base of presence/absence of each ant or hemipteran species on a given host-plant species. Ants' feeding behaviour was surveyed with special references to plant products collected either from plants or hemipterans. Their associated hemipteran species were also recorded when it was the case.

\section{Identification of the collected insects}

At the laboratory, the identification of the collected insects were done by comparing specimens to those in the collection of the Laboratory of Zoology of University of Yaoundé 1 and using the following keys: Blackman and Eastop (2000) for aphids, Hölldobler and Wilson (1990), Bolton (1994) and Taylor (http:/www.antbase.org/, April, $\left.06^{\text {th }}, 2015\right)$ for ants. These identifications were later confirmed by comparing specimens to those in the Voucher collection of the Royal Museum for Central Africa (RMCA) at Tervuren (Belgium) during an internship of DCA. Some other hemipterans such as mealybugs were determined with the help of taxonomists of the CIRAD-CBGP at Montpellier (France) during an internship of DCA.

\section{Food resources exploited by ants}

Once different food resources targeted by ant species in the farms identified, the occurrence of each harvested resource was computed with reference to the number of time a given ant species was observed feeding on it on a given host-plant species.

\section{Variation of the occurrence of ant- hemipteran associations}

Occurrences of each pair of ant and hemipteran species on different host-plants was computed. According to their global occurrence on host-plant species, associations were grouped in three categories viz: most frequent (relative frequency of occurrence $\geq$ $10 \%)$, less frequent $(1 \% \leq$ relative frequency of occurrence $<10 \%$ ) and rare (relative frequency of occurrence $<1 \%$ ). 
The effect of host-plant species on the variation of the most occurring associations was tested using Chi-squared test (GLM proc); then binomial family was applied for adjustment as recommended by Crawley (2007) for the proportion data. TurkeyHSD pairwise comparison test was also applied when necessary in order to find out the variation source between occurrences of associations on a pair of host-plant species. Values of probabilities were adjusted by using the sequential Bonferroni procedure for pairwise comparisons and the results were appreciated at the $5 \%$ threshold.

\section{Characterization of ant fauna and relationships with hemipterans}

Interactions between hemipteran and ant species on a given host-plant was studied using spearman correlation test (r). Analysis were done using package Corrplot (Wei and Simko, 2017) for R. With $r \geq 1$ or $\leq-1$, ant and hemipteran species were either positively or negatively associated on a given host-plant species; with $r=0$, there was no relationship between ants and hemipterans on a given hostplant. The results were appreciated at the 5\% confidence interval.

\section{RESULTS}

\section{Hemipteran and ant faunas}

The hemipteran fauna associated with studied plants was relatively diversified (Aléné et al. unpublished data), with five families interacting with ant species. These included Aphididae represented by Aphis fabae, Aphis gossypii, Macrosiphum euphorbiae, and Aulacorthum solani, Aleyrodidae represented by Bemisia tabacci, Membracidae (Centrotus globifer, Leptocentrus bolivari, Trichoceps cf varipennis), Cicadellidae (Jacobiasca sp., Empoasa sp., Amrasca sp.) and mealybugs (Coccoidea) (Planococcus sp., Phenacoccus sp., Orthezia insignis) (Table 1).

Their associated ant fauna included three subfamilies: Dolichodinae represented by three species (Axinidris sp., Tapinoma sp., Technomyrmex sp.), Formicinae with three species (Camponotus maculatus, Camponotus flavomarginatus, Lepisiota sp.) and Myrmicinae with eight species (Cardiochondyla sp., Monomorium bicolor, Myrmicaria opaciventris, Pheidole magacephala, Pheidole sp., Pheidole speculifera, Tetramorium sericeiventre, Tetramorium sp.) (Table 2).

\section{Plant food resources exploited by ants}

Apart from their predatory behaviour, ant diet in the present study included various plant fluids among which sap directly extracted from host-plant tissues and honeydew indirectly obtained through hemipterans.

The sap diet (18 observations) was mainly observed in $M$. opaciventris with eight occurences (44.44\%) on Solanum melongena and $C$. flavomarginatus with five occurrences (27.78\%) on $S$. melongena. The species $M$. opaciventris was sometimes observed feeding on sap from wounded parts of Abelmoschus esculentum.

The honeydew regime was observed in all the ant species recorded. For this purpose, they were closely associated with hemipteran species.

\section{Variation of the occurrence of ant- hemipteran associations}

Among the 38 ant-hemipteran associations pointed out from this survey (Table 3), 11 of them, involving aphids, presented the highest occurrences ranged from 10 (i.e. relative frequency of $7.52 \%$ ) to 48 (i.e. relative frequency of $36.09 \%$ ); 17 of them, involving aphids and mealybugs, were less frequent with occurrences ranged from 2 $(1.50 \%)$ to $9(6.77 \%)$; and finally 10 associations involving aphids and other hemipterans namely mealybugs, membracids and cicadellids, were rare with occurrences of $1(0.75 \%)$. The occurrences of the most frequent associations showed highly significant variations from one plant species to another $\left(\mathrm{P}<10^{-3}\right)$. For instance, the most recurrent associations included $C$. flavomarginatus $-M$. euphorbiae occurring 
mostly on eggplant with a relative frequency of $100 \%$ and on tomato with a relative frequency of $70.83 \%, M$. opaciventris $-M$. euphorbiae occurring mostly on eggplant $(100 \%)$, seldom on tomato $(29.17 \%)$ and on okra (12\%), M. opaciventris $-A$. fabae solely encountered on African nightshade (100\%), $P$. megacephala-M. euphorbiae occurring mostly on eggplant (56.67\%), sometimes on tomato (29.17\%), C. flavomarginatus-A. fabae occurring merely on African nightshade (70\%), C. flavomarginatus $-A$. solani occurring mostly on hot-pepper $(66.67 \%)$ and occasionally on eggplant (13.33\%), Tapinoma sp.-M. euphorbiae exclusively on eggplant (60\%), M. opaciventris-A. gossypii mostly recorded on okra (44\%) and sometimes on African nightshade (10\%), M. opaciventris- $A$. solani on hot-pepper $(29.17 \%)$ and on eggplant (23.33\%), Technomyrmex sp.-M. euphorbiae on tomato $(37.50 \%)$ and on okra (16\%), Technomyrmex sp. $-A$. gossypii exclusively recorded on okra (40\%).

Among the less frequent associations, the occurrences of some of them varied highly significantly from one plant to another, they were $M$. opaciventris-Mealybugs exclusively recorded on eggplant (30\%), T. sericeiventreM. euphorbiae recorded on eggplant (23.33\%) and on tomato (4.17\%), Technomyrmex sp.-A. fabae only recorded on African nightshade (20\%), and C. flavomarginatus-Mealybugs exclusively encountered on eggplant (20\%).

Among the rare associations, those involving M. opaciventris and Membracidae (T. varipenis and $C$. globifer) were exclusively recorded on eggplant with very weak occurrences, 1 (3.33\%). This was also the case with Tetramorium sp.-Cicadelidae on eggplant.

In terms of diversity, the number of ant-hemipteran associations was the highest on eggplant (20), then on okra (10), on pepper (8), on African nightshade (7), and lastly on tomato (6). However, the associations recorded on okra were mostly among the less frequent and rare whereas those on tomato were mainly among the most frequent. The associations hosted by the eggplant belonged to the three categories, most frequent, less frequent and rare.

\section{Ant-aphids relationships}

Owing the importance of ant-aphid associations, the analysis of relationships amongst the two groups revealed different pattern of interaction between ants and aphids (Table 4). So, positive and significant correlations were observed between the aphid M. euphorbiae and five ant species, $C$. flavomarginatus, $\quad M$. opaciventris, $P$. megacephala, Tapinoma sp. and $T$. sericeiventre on eggplant. The same trend was observed between the aphid A. solani and three ant species, $C$. flavomarginatus, $M$. opaciventris and $P$. megacephala on $S$. melongena too. Correlations were also positive and significant between A. gossypii and two ant species, $C$. flavomarginatus and $P$. megacephala on okra. The same trend was observed on African nightshade between $A$. fabae and ant two ant species, $C$. flavomarginatus and M. opaciventris. On hot pepper, positive and significant correlations were raised out between $A$. solani and two ant species, M. opaciventris and Pheidole sp. On tomato, M. euphorbiae determined positive and significant correlations with four ant species $M$. opaciventris, M. bicolor, $P$. megacephala and Technomyrmex sp.

For some other aphid species, the correlations with ant species were either positive and non-significant or negative and non-significant, especially when the aphid was not on its favourite host-plant (Table 4), suggesting that their simultaneous presence on these host-plants was not compulsory. This could also be due to the vagrant behaviour of some ants whose food resources were not derived from a single hemipteran species. 
Table 1: List of hemipterans encountered with ants in the trap garden at Nkolondom.

\begin{tabular}{|c|c|c|c|c|c|}
\hline Families & Aphididae & Aleyrodidae & Coccoidea & Membracidae & Cicadellidae \\
\hline \multirow{6}{*}{ Species } & Aphis fabae Scopoli 1763 & Bemisia tabaci (Gennadius, 1889) & Planococcus sp. & Centrotus globifer Pelaez, 1935 & Jacobiasca sp. \\
\hline & Aphis gossypii Glover 1877 & & Phenacoccus sp. & Leptocentrus bolivari Pelaez, 1935 & Empoasa sp. \\
\hline & Aulacorthum solani & & & Trichoceps cf varipennis Signoret, & \\
\hline & Kaltenbacher 1843 & & Orthezia insignis Browne 1887 & 1858 & Amrasca sp. \\
\hline & Macrosiphum euphorbiae & & & & \\
\hline & Thomas 1878 & & & & \\
\hline
\end{tabular}

Table 2: List of ants encountered with hemipterans in the trap garden at Nkolondom.

\begin{tabular}{|c|c|}
\hline Sub-families & Species \\
\hline \multirow{3}{*}{ Formicinae } & Camponotus flavomarginatus Mayr, 1862 \\
\hline & Camponotus maculatus Fabricius, 1782 \\
\hline & Lepisiota $\mathrm{sp}$. \\
\hline \multirow{5}{*}{ Myrmicinae } & Myrmicaria opaciventris Emery, 1893 \\
\hline & Pheidole megacephala Fabricius, 1793 \\
\hline & Pheidole speculifera Emery, 1877 \\
\hline & Pheidole sp. \\
\hline & Monomoriun bicolor Emery, 1877 \\
\hline
\end{tabular}


D. C. ALENE et al. / Int. J. Biol. Chem. Sci. 13(3): 1775-1788, 2019

Tertramurium sericiventre Emery, 1877

\begin{tabular}{ll}
\cline { 2 - 2 } Tertramurium $\mathrm{sp}$. \\
\cline { 2 - 2 } Dolichoderinae & Axinidris $\mathrm{sp}$. \\
\cline { 2 - 2 } & Tapinoma $\mathrm{sp}$ \\
\cline { 2 - 2 } & Technomyrmex $\mathrm{sp}$ \\
\hline
\end{tabular}

Table 3: Variations of occurrence and Frequency of ant-hemipteran associations on the studied host-plants.

\begin{tabular}{|c|c|c|c|c|c|c|c|}
\hline \multirow{3}{*}{ Ant-Hemiptera associations } & \multicolumn{5}{|c|}{ Plant species } & \multirow{3}{*}{$\begin{array}{c}\text { Total } \\
(n=133)\end{array}$} & \multirow{3}{*}{$\chi^{2}$ test (GLM Proc.) } \\
\hline & $\mathbf{S M}(\mathbf{n}=\mathbf{3 0})$ & $\mathrm{AE}(\mathrm{n}=\mathbf{2 5})$ & SSc $(n=30)$ & $\mathrm{CA}(\mathrm{n}=24)$ & SL $(n=24)$ & & \\
\hline & \multicolumn{5}{|c|}{ Most frequent } & & \\
\hline Camponotus flavomarginatus-Macrosiphum euphorbiae & $30(100.0)^{\mathrm{a}}$ & $0(0.00)^{b}$ & $0(0.00)^{\mathrm{b}}$ & $1(4.17)^{\mathrm{bc}}$ & $17(70.83)^{\mathrm{bd}}$ & $48(36.09)$ & $\chi^{2}=136.66 ; \mathrm{P}<10^{-3} * * *$ \\
\hline Myrmicaria opaciventris-Macrosiphum euphorbiae & $30(100.0)^{\mathrm{a}}$ & $3(12.0)^{\mathrm{bc}}$ & $0(0.00)^{\mathrm{b}}$ & $0(0.00)^{\mathrm{b}}$ & $7(29.17)^{\mathrm{bd}}$ & $40(30.08)$ & $\chi^{2}=115.34 ; \mathrm{P}<10^{-3} * * *$ \\
\hline Myrmicaria opaciventris-Aphis fabae & $0(0.00)^{b}$ & $0(0.00)^{b}$ & $30(100.00)^{\mathrm{a}}$ & $0(0.00)^{b}$ & $0(0.00)^{b}$ & $30(22.56)$ & $\chi^{2}=142.01 ; \mathrm{P}<10^{-3} * * *$ \\
\hline Pheidole megacephala-Macrosiphum euphorbiae & $17(56.67)^{\mathrm{a}}$ & $0(0.00)^{b}$ & $0(0.00)^{\mathrm{b}}$ & $0(0.00)^{\mathrm{b}}$ & $7(29.17)^{\mathrm{bc}}$ & $24(18.05)$ & $\chi^{2}=55.54 ; \mathrm{P}<10^{-3} * * *$ \\
\hline Camponotus flavomarginatus-Aphis fabae & $0(0.00)^{\mathrm{b}}$ & $0(0.00)^{b}$ & $21(70.00)^{\mathrm{a}}$ & $0(0.00)^{b}$ & $0(0.00)^{b}$ & $21(15.79)$ & $\chi^{2}=79.37 ; \mathrm{P}<10^{-3} * * *$ \\
\hline Camponotus flavomarginatus-Aulacortum solani & $4(13.33)^{\mathrm{a}}$ & $0(0.00)^{b}$ & $0(0.00)^{b}$ & $16(66.67)^{b c}$ & $0(0.00)^{b}$ & $20(15.04)$ & $\chi^{2}=58.50 ; \mathrm{P}<10^{-3} * * *$ \\
\hline Tapinoma sp.-Macrosiphum euphorbiae & $18(60.0)^{\mathrm{a}}$ & $0(0.00)^{b}$ & $0(0.00)^{b}$ & $0(0.00)^{b}$ & $0(0.00)^{b}$ & $18(13.53)$ & $\chi^{2}=65.06 ; \mathrm{P}<10^{-3} * * *$ \\
\hline Myrmicaria opaciventris-Aphis gossypii & $0(00.0)^{\mathrm{b}}$ & $11(44.00)^{\mathrm{a}}$ & $3(10.00)^{\mathrm{bc}}$ & $0(0.00)^{\mathrm{b}}$ & $0(0.00)^{\mathrm{b}}$ & $14(10.53)$ & $\chi^{2}=35.71 ; \mathrm{P}<10^{-3} * * *$ \\
\hline
\end{tabular}


D. C. ALENE et al. / Int. J. Biol. Chem. Sci. 13(3): 1775-1788, 2019

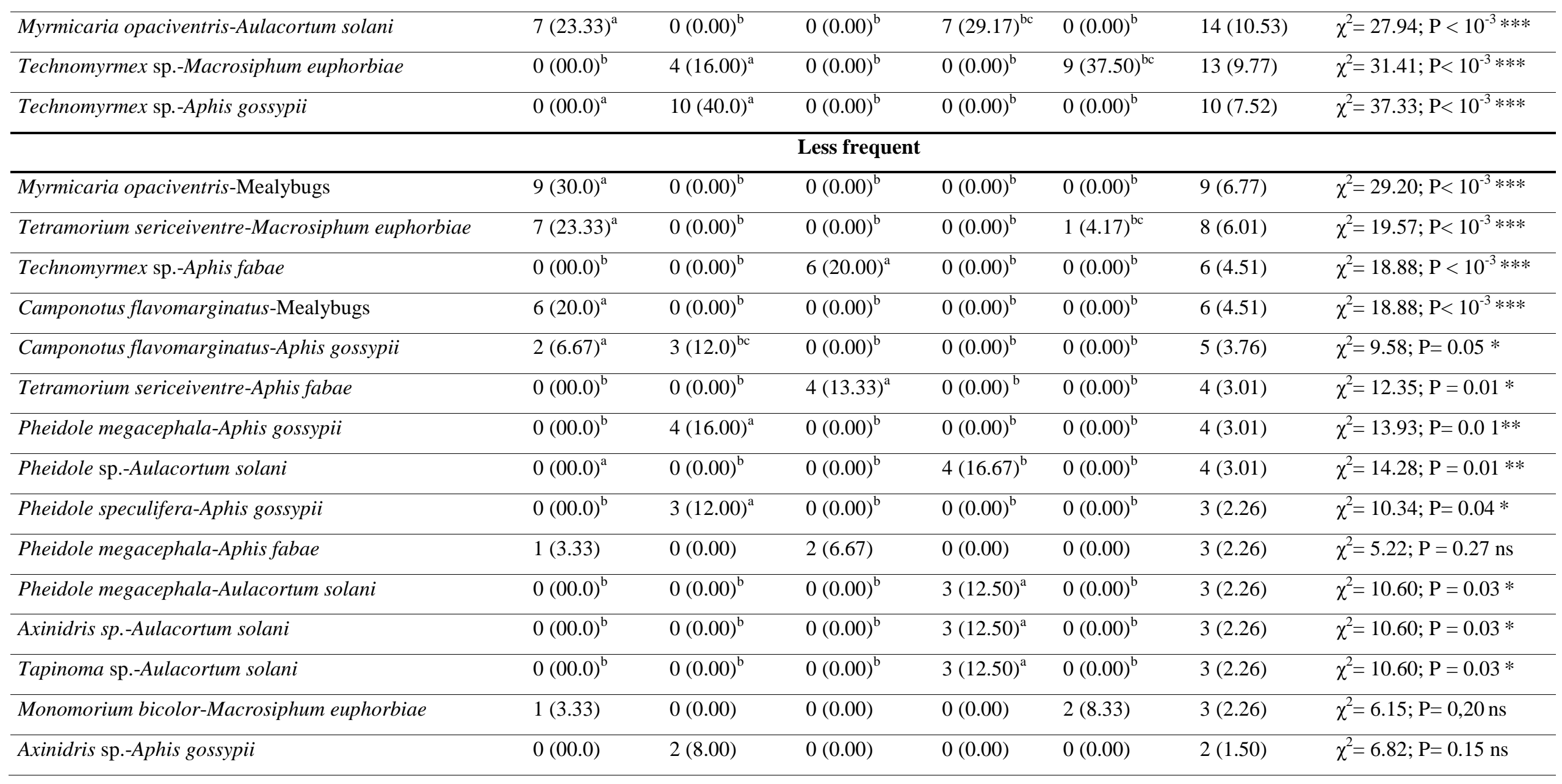


D. C. ALENE et al. / Int. J. Biol. Chem. Sci. 13(3): 1775-1788, 2019

\begin{tabular}{|c|c|c|c|c|c|c|c|}
\hline Tetramorium sp.-Macrosiphum euphorbiae & $2(6.67)$ & $0(0.00)$ & $0(0.00)$ & $0(0.00)$ & $0(0.00)$ & $2(1.50)$ & $\chi^{2}=6.06 ; \mathrm{P}=0.19 \mathrm{~ns}$ \\
\hline Tapinoma sp.-Mealybugs & $2(6.67)$ & $0(0.00)$ & $0(0.00)$ & $0(0.00)$ & $0(0.00)$ & $2(1.50)$ & $\chi^{2}=6.06 ; \mathrm{P}=0.19 \mathrm{~ns}$ \\
\hline \multicolumn{8}{|c|}{ Rare } \\
\hline Camponotus maculatus-Aphis fabae & $1(3.33)$ & $0(0.00)$ & $0(0.00)$ & $0(0.00)$ & $0(0.00)$ & $1(0.75)$ & $\chi^{2}=3.00 ; \mathrm{P}=0.56 \mathrm{~ns}$ \\
\hline Lepisiotas sp.-Aphis fabae & $0(00.0)$ & $0(0.00)$ & $1(3.33)$ & $0(0.00)$ & $0(0.00)$ & $1(0.75)$ & $\chi^{2}=3.00 ; \mathrm{P}=0.56 \mathrm{~ns}$ \\
\hline Cardiocondyla sp.-Aulacortum solani & $1(3.33)$ & $0(0.00)$ & $0(0.00)$ & $0(0.00)$ & $0(0.00)$ & $1(0.75)$ & $\chi^{2}=3.00 ; \mathrm{P}=0.56 \mathrm{~ns}$ \\
\hline Tetramorium sericeiventre-Aulacortum solani & $0(00.0)$ & $0(0.00)$ & $0(0.00)$ & $1(4.17)$ & $0(0.00)$ & $1(0.75)$ & $\chi^{2}=3.00 ; P=0.48 \mathrm{~ns}$ \\
\hline Pheidole speculifera-Macrosiphum euphorbiae & $0(00.0)$ & $1(4.00)$ & $0(0.00)$ & $0(0.00)$ & $0(0.00)$ & $1(0.75)$ & $\chi^{2}=3.37 ; \mathrm{P}=0.50 \mathrm{~ns}$ \\
\hline Technomyrmex sp.-Mealybugs & $0(00.0)$ & $1(4.00)$ & $0(0.00)$ & $0(0.00)$ & $0(0.00)$ & $1(0.75)$ & $\chi^{2}=3.38 ; \mathrm{P}=0.50 \mathrm{~ns}$ \\
\hline Myrmicaria opaciventris-Tricocep cf. varipenis & $1(3.33)$ & $0(0.00)$ & $0(0.00)$ & $0(0.00)$ & $0(0.00)$ & $1(0.75)$ & $\chi^{2}=3.00 ; \mathrm{P}=0.56 \mathrm{~ns}$ \\
\hline Myrmicaria opaciventris-Centrotus globifer & $1(3.33)$ & $0(0.00)$ & $0(0.00)$ & $0(0.00)$ & $0(0.00)$ & $1(0.75)$ & $\chi^{2}=3.00 ; \mathrm{P}=0.56 \mathrm{~ns}$ \\
\hline Tetramorium sp.-Cicadelidae & $1(3.33)$ & $0(0.00)$ & $0(0.00)$ & $0(0.00)$ & $0(0.00)$ & $1(0.75)$ & $\chi^{2}=3.00 ; \mathrm{P}=0.56 \mathrm{~ns}$ \\
\hline Pheidole megacephala-Mealy bugs & $1(3.33)$ & $0(0.00)$ & $0(0.00)$ & $0(0.00)$ & $0(0.00)$ & $1(0.75)$ & $\chi^{2}=3.00 ; \mathrm{P}=0.56 \mathrm{~ns}$ \\
\hline
\end{tabular}

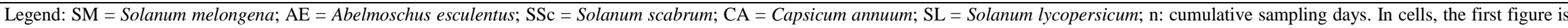

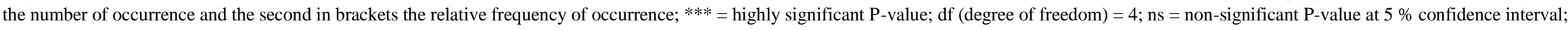
different letters in superscript indicate differences or similitudes between occurrences in pairs of plant species after pairwise comparison. 
D. C. ALENE et al. / Int. J. Biol. Chem. Sci. 13(3): 1775-1788, 2019

Table 4: Relationships between ant and hemipteran populations on target host-plants.

\begin{tabular}{|c|c|c|c|c|c|c|c|c|}
\hline \multirow{3}{*}{ Ants species } & \multicolumn{8}{|c|}{ Host-plant species } \\
\hline & \multicolumn{2}{|c|}{$\mathbf{S M}$} & \multicolumn{2}{|r|}{$\mathbf{A E}$} & \multicolumn{2}{|c|}{ SSc } & \multirow{2}{*}{$\frac{\text { CA }}{\text { A. solani }}$} & \multirow{2}{*}{\begin{tabular}{|c|} 
SL \\
M. euphorbiae
\end{tabular}} \\
\hline & M. euphorbiae & A. solani & A. gossypii & M. euphorbiae & A. fabae & A. gossypii & & \\
\hline Axinidrix sp. & & & $-0,17$ & 0,22 & & & & \\
\hline Camponotus flavomarginatus & $0.92 *$ & $0.29 *$ & $0.45^{*}$ & $-0,23$ & $0.38 *$ & 0,24 & 0,39 & 0,08 \\
\hline Myrmicaria opaciventris & $0.94 *$ & $0.30 *$ & 0,04 & $-0,1$ & $0.62 *$ & 0,35 & $0.47 *$ & $0.43 *$ \\
\hline Monomorium Bicolor & & & & & & & & $0.44 *$ \\
\hline Pheidole megacephala & $0.61 *$ & $0.35 *$ & $0.41 *$ & $-0,06$ & & & 0,01 & $0.67 *$ \\
\hline Pheidole speculifera & & & 0,29 & 0,26 & & & & \\
\hline Pheidole sp. & & & & & & & $0.57 *$ & \\
\hline Tapinoma sp. & $0.63 *$ & 0,13 & & & & & 0,12 & \\
\hline Tetramorium cericiveintris & $0.47 *$ & 0,02 & & & 0,16 & $-0,13$ & & 0,06 \\
\hline Technomyrmex sp. & & & 0,37 & 0,11 & 0,13 & $-0,16$ & & $0.57 *$ \\
\hline
\end{tabular}

Legend: $\mathrm{SM}=$ Solanum melongena; $\mathrm{CA}=$ Capsicum annuum; $\mathrm{AE}=$ Abelmoschus esculentus; $\mathrm{SSc}=$ Solanum scabrum; $\mathrm{SL}=$ Solanum lycopersicum . Values in the table represent Spearman correlation test (r); $*=$ significance at $5 \%$ confidence interval. 


\section{DISCUSSION}

In the present study, only two ant species consuming sap were observed, $M$. opaciventris and C. flavomarginatus. This suggests that honeydew was the main food resource sought by ants in our trap garden. In fact, it is known that honeydew is an important source of compensation for the high energy requirement, notably in the carbohydrate, for ant metabolism (Fischer et al., 2005). In addition, Blüthgen and Fiedler (2004) reported tritrophic interactions between ants, hemipterans and plants. Ants would prefer honeydew to sap because they are unable to feed directly on the sap (Delabie, 2001). The species M. opaciventris, out of our experimental garden, have often been observed chewing young parts of okra and absorbing sap (personal observation). This behavior can induce serious lesions to plant, thus letting flow the sap that it consumes. Then C. flavomarginatus takes advantage of these lesions. Such feeding behaviour is well studied by Blüthgen et al. (2004). Also, Kenne (2006) reported workers of M. opaciventris very often chewing young branches and buds of Vernonia amygdalina Delile in order to feed on sap from wounded tissues. Apart from these two ant species, $P$. megacephala is known to consume nectar from flower nectaries (Lach et al., 2009). On the hostplants involved in the present study, this ant was also present and would gather nectar.

In the current survey, no ant seemed to depend exclusively on the honeydew produced by a single species of hemipteran. In turn hemipterans also could do well without the presence of ants as observed by Steiner et al. (2004). In this context, it would be too pretentious to state about symbiosis in anthemipteran associations. It is shown from our results that a species of ant may tend several species of hemipteran as much as they provide them with honeydew; this observation has already been made by Yoo et al. (2013). These associations are mostly of the oppositionist mutualistic type described by Maravalhas and Morais (2009).

Ants that exploit honeydew may either pose more or less nuisance problems to hostplants because of the protection they supply to plant sap-suckers (Styrsky and Eubanks,
2007). Indeed, great damage such as leaf curling or necrosis was observed in the present study on African nightshade and on tomato. Ant would also protect plants from other phytophagous insects as observed by some authors (Moreira and Del-Claro, 2005; Styrsky and Eubanks, 2007).

Observed associations showed that ants were mostly attracted by aphids. The most recurrent were $C$. flavomarginatus $-M$. euphorbiae, M. opaciventis-M. euphorbiae, M. opaciventris-A. fabae, P. megacephala-M. euphorbiae, C. flavovamarginatus-A. fabae. With non-aphid hemipterans, the most recurrent associations were those involving $M$. opaciventris and mealybugs or $C$. flavomarginatus and mealybugs. In fact, in trophobiotic interactions between ants and hemipterans, as pointed out by Delabie (2001), ants are likely to be more attracted by Sternorrhyncha than Cicadomorpha (Membracidae, Ciccadellidae). The high frequency of ant-aphid associations would be explained either by the huge amount and the quality of the honeydew they could produce and/or by the inability for most of aphids to move by themselves from one plant to another; then ant would serve as vehicle duties for these plant-lice (Delabie, 2001). It's also to be noticed that the most recurrent associations were made up by aphids and behavioural dominant ants, $M$. opaciventris, $P$. megacephala, etc., which are known to be territorially aggressive, and some other such as C. flavomarginatus, which are known to behave as extirpators according to Delsinne et al. (2007). Anyhow, there is no strict specificity in these associations. Furthermore ants are considered as opportunist in the choice of the hemipteran species they tend (Delabie, 2001; Blüthgen et al., 2006).

In this study, while some anthemipteran associations recorded were closely related to a specific host-plant with high frequencies, the majority of these associations were present on eggplant with high or low frequencies. This might be due to the fact that eggplant, an exotic selected plant, is not among the main crops produced at the Nkolondom basin. Hence, it tends to attract more insects species which would taste this new host or because of lack of defence 
features, inherent to continuous selection of the plant (Chen et al., 2018).

In our results, positive and significant correlations were observed between populations of some ant species and those of aphid species. This shows that the presence of ants contributes to the fitness of the aphids as observed by Stadler and Dixon (2005). Moreover, it has been demonstrated that for a given species of aphid, the amount of honeydew linked to the number of individuals would be a major factor determining the recruitment of more ants in the colonies (Mailleux et al., 2003). In the present study, from one plant to another, the ants' species as well as the hemipterans' species in association varied. This could be due to the specificity of aphids vis-à-vis of host-plants.

\section{Conclusion}

From the present study, it was observed that ants fed preferentially on the honeydew excreted by hemipterans, mainly aphids with which they were associated. These associations, although very diversified, were distinctively related to specific host-plants, pointing out the oligophagous regime of these aphids. It also raised out that ants were not always specialized to a single hemipteran species, probably because of the vagrant behaviour of some of them who would forage on diverse foods without any specialization. Definitely, ants indirectly cause damage to plants by nurturing hemipteran herds whose activity spoils plants from their nutrients by sucking the sap. Consequently, further integrated management strategies of these hemipteran pests in market-oriented cropping systems should take into account the associated ant community.

\section{COMPETING INTERESTS}

The authors do not have any competing interests to declare.

\section{AUTHORS' CONTRIBUTIONS}

DCA and CDL conceived the project, DCA and YMM collected data and ZT did statistical analyses. DCA wrote the manuscript and all the co-authors read and approved the manuscript.

\section{ACKNOWLEDGEMENTS}

We are grateful to late Mr Léonard Enama Ngah, an inhabitant of Nkolondom, who agreed to lend us a piece of land for field work.

\section{REFERENCES}

Blackman RL, Eastop VP. 2000. Aphids of the world's crops. An Identification and Information Guide (2nd edition). John Wiley: Chichester, London; 466 p.

Blüthgen N, Fiedler K. 2004. Competition for composition: lessons from nectar-feeding ant communities. Ecology, 85: 14791485. DOI: https://doi.org/10.1890/030430 .

Blüthgen N, Menzel F, Blüthgen N. 2006. Measuring specialization in species interaction networks. BMC Ecology, 6(9).

DOI: http://dx.doi.org/10.1186/1472-6785-6-9.

Blüthgen N, Gottsberger G, Fiedler K. 2004. Sugar and amino acid composition of ant-attended nectar and honeydew sources from an australian rainforest. Australian Ecology, 29(4): 418-429. DOI: http://dx.doi.org/10.1111/j.14429993.2004.01380.x.

Bolton B. 1994. Identification Guide to the Ant Genera of the World. Harvard University Press: Cambridge MA.

Brault V, Uzest M, Monsion B, Jacquot E, Blanc S. 2010. Aphids as transport devices for plant viruses. Comptes Rendues Biologies, 333(6-7): 524-538. DOI: https://doi.org/10.1016/j.crvi.2010.04.00 1.

Crawley MJ. 2007. The $R$ book. John Wiley Sons Ltd, The Atrium, Southern Gate, Chichester, West Sussex PO19 8SQ, England.

Chen YH, Ruiz-Arocho J, von Wettberg EJB. 2018. Crop domestication: anthropogenic effects on insect-plant interactions in agroecosystems. Current Opinion in Insect Sciences, 29: 56-63. DOI: https://doi.org/10.1016/j.cois.2018.06.00 4.

Delabie JHC. 2001. Trophobiosis between Formicidae and Hemiptera 
(Sternorrhyncha and Auchenorrhyncha): an overview. Neotropical Entomology, 30: 501-516. DOI: http://dx.doi.org/10.1590/S1519566X2001000400001.

Delsinne T, Roisin Y, Leponce M. 2007. Spatial and temporal foraging overlaps in a Chacoan ground-foraging ant assemblage. Journal of Arid Environments, 71: 29-44. DOI: http://dx.doi.org/10.1016/j.jaridenv.2007 .02 .007 .

Djiéto-Lordon C, Aléné DC, Reboul J. 2007. Contribution à la connaissance des insectes associés aux cultures maraîchères dans les environs de Yaoundé-Cameroun. Cameroon Journal of Biological and Biochemical Sciences, 15: 1-13.

Fischer MK, Völkl W, Hoffmann KH. 2005. Honeydew production and honeydew sugar composition of polyphagous black bean aphid, Aphis fabae (Hemiptera: Aphididae) on various host-plants and implications for ant-attendance. European Journal of Entomology, 102(2): $\quad 155-160 . \quad$ DOI: http://dx.doi.org/10.14411/eje.2005.025.

Guerrieri E, Digilio MC. 2008. Aphid-plant interactions: a review. Journal of Plant Interactions, 3(4): 223-232. DOI: http://dx.doi.org/10.1080/174291408025 67173.

Hampton RO, Jensen A, Hagel GT. 2005. Attributes of bean yellow mosaic potyvirus transmission from clover to snap beans by four species of aphids (Homoptera: Aphididae). Journal of Economic Entomology, 98: 1816-1823. DOI: https://doi.org/10.1603/0022-049398.6.1816.

Hölldobler B, Wilson EO. 1990. The Ants. The Belknap Press of Harvard University: Cambridge, Massachusetts.

Jones DR. 2003. Plant virus transmitted by whitefly. European Journal of Plant Protection, 109: 195-219. http://dx.doi.org/10.1023/A:1022846630 513.

Kenne M. 2006. Évaluation des possibilités d'utilisation d'une espèce de fourmi terricole dominante comme auxiliaire de lutte contre les insectes phytophages. Mémoire d'habilitation à diriger des recherches. Université Paul Sabatier, Toulouse III; 104p.

Lach L, Hobbs RJ, Majer JD. 2009. Herbivory-induced extrafloral nectar increases native and invasive ant worker survival. Population Ecology, 51(2): 237-243.

DOI: https://doi.org/10.1007/s10144-0080132-2.

Lehouck VS, Bonte DB, Dekoninck W, Maelfait, JPE. 2004. Trophobiotic relationships berween ants (Hymenoptera: Formicidae) and Tettigometridae (Hemiptera: Fulgoromorpha) in the grey dunes of Belgium. European Journal of Entomology, 101: 547-553. DOI: https://doi.org/10.14411/eje.2004.078.

Mahob RJ, Ndoumbè-Nkeng M, Ten Hoopen GM, Dibog L, Nyassé S, Rutherford M, Mbenoun M, Babin R, Amang A Mbang J, Yede Y, Bilong Bilong CF. 2014. Pesticides use in cocoa sector in Cameroon: characterization of supply source, nature of actives ingredients, fashion and reasons for their utilization. International Journal of Biological and Chemical Sciences, 8(5): 1976-1989. DOI: http://dx.doi.org/10.4314/ijbcs.v8i5.3.

Mahob RJ, Nsoga Etam P B, Dibog L, Babin R, Voula AV, Begoude D., Fotso Toguem YG, Baleba L, Owona Ndongo PA, Bilong Bilong CF. 2018. Assessment of the effect of cocoa mosquito mirid true bug, Helopeltis sp. (Hemiptera: Miridae) on the cocoa (Theobroma cacao L.) production in Cameroon (Central Africa). International Journal of Biological and Chemical Sciences, 12(4): 1865-1875. DOI: https://dx.doi.org/10.4314/ijbcs.v12i4.27

Mailleux AC, Deneubourg JL, Detrain C. 2003. Regulation of ants' foraging to resource productivity. Proceeding of the Royal Society B: Biological Sciences, 270(1524): $\quad$ 1609-1616. DOI: https://doi.org/10.1098/rspb.2003.2398. 
Maravalhas J, Morais HC. 2009. Association between ants and a leafhopper (Cicadellidae: Idiocerinae) in the Central Brazilian Cerrado. Florida Entomologist, 92(4): 563-568. DOI: https://doi.org/10.1653/024.092.0405.

Moreira VSS, Del-Claro K. 2005. The Outcomes of an Ant-Treehopper Association on Solanum lycocarpum St. Hill: Increased Membracid Fecundity and Reduced Damage by Chewing Herbivores. Neotropical Entomology, 34(6): 881-887. DOI: https://doi.org/10.1590/S1519566X2005000600002.

Nasruddin A, Stocks IC. 2014. First report of Economic injury due to the spiraling whitefly (Hemiptera: Aleyrodidae) on Pepper in Indonesia. Scientific Notes Florida Entomologist, 97(3): 1255-1259. DOI: https://doi.org/10.1653/024.097.0337.

Ng JCK, Perry KL. 2004. Transmission of plant viruses by aphid vectors. Molecular Plant Pathology, 5(5): 505511. DOI: https://doi.org/10.1111/J.13643703.2004.00240.X.

Oliver TH, Mashanova A, Leather SR, Cook JM, Jasen VAA. 2007. Ant semiochemicals limit apterous aphid dispersal. Proceedings of the Royal Society B, 274(1629): 3127-3131. DOI: https://doi.org/10.1098/rsp b.2007.1251.

Palumbo JC, Natwick ET. 2010. The Bagrada bug (Hemiptera: Pentatomidae): A new invasive pest of cole crops in Arizona and California. Online. Plant Health Progress.

DOI: https://doi.org/10.1094/PHP-2010-062101-BR.

Stadler B, Dixon AFG. 2005. Ecology and evolution of Aphid-Ant Interactions.
Annual Review of Ecology Evolution and Systematics, 36: 345-372. DOI: https://doi.org/10.1146/annurev.ecolsys. 36.091704.175531.

Steiner FM, Schlick-Steiner BC, Holzinger WE, Komposch C, Pazoutova S, Sanetra M, Christian E. 2004. A novel relationship between ants and a leafhopper (Hymenoptera: Formicidae; Hemiptera: Cicadellidae). European Journal of Entomology, 101(4): 689-692. DOI: https://doi.org/10.14411/eje.2004.090.

Styrsky JD, Eubanks MD. 2007. Ecological consequences of interactions between ants and honeydew-producing insects. A Review. Proceedings of the Royal society Biology, 274 (1607): 151-164. DOI: https://doi.org/10.1098/rspb.2006.3701.

Taylor (http:/www.antbase.org/, April, $06^{\text {th }}$, 2015).

Tendeng E, Labou B, Djiba S, Diarra K. 2017. Actualisation de l'entomofaune des cultures maraîchères en Basse Casamance (Sénégal). International Journal of Biological and Chemical Sciences, 11(3): 1021-1028. DOI: https://dx.doi.org/10.4314/ijbcs.v11i3.7.

Temple L. 2001. Quantifications des productions et des échanges de fruits et légumes au Cameroun. Cahiers Agricultures, 10: 87-94.

Wei T, Simko V. 2017. R package "corrplot": Visualization of a Correlation Matrix (Version 0.84). https://github.com/taiyun/corrplot.

Yoo HJS, Kizner MC, Holway DA. 2013. Ecological effects of multi-species, anthemipteran mutualisms in citrus. Ecological Entomology, 38(5): 505-514. DOI: https://doi.org/10.1111/een.12042. 